Research Article

\title{
In-Vitro Propagation for Conserving the Gems of the Hills Caralluma tuberculata to Rescue the Valuable Endangered Medicinally Important Plant
}

\section{Muhammad Taqi ${ }^{1}$, Shazia Erum ${ }^{2}$, Shamaila Rasheed ${ }^{2}$, Sadar Uddin Siddiqui ${ }^{2}$ and Shakeel Ahmad Jatoi ${ }^{2 *}$}

${ }^{1}$ Department of horticulture, University of Agriculture, Peshawar, Pakistan; ${ }^{2}$ Bio Resources Conservation Institute, NARC, Islamabad, Pakistan.

Abstract | Overharvesting has posed pressure on Caralluma tuberculata plants resulting in the disappearance of its wild populations in different mountainous regions in Pakistan. A proficient way for large-scale and fast propagation of $C$. tuberculata through in-vitro organogenesis was carried out at in-vitro lab, Bio-resources Conservation Institute, NARC, Islamabad, Pakistan. Nodal-tips as explants were grown on MS salts enriched with diverse plant growth regulators including BAP, NAA, Kin and 2,4-D, alone as well as in combinations. The highest growth response for callusing $78.3 \%$ was observed in BAP $(0.5 \mathrm{mg} / \mathrm{L})$ in combination with Kinetin $(0.25 \mathrm{mg} / \mathrm{L})+\mathrm{NAA}(2 \mathrm{mg} / \mathrm{L})$ followed by $65 \%$ at $2 \mathrm{mg} / \mathrm{L}$ of $2,4-\mathrm{D}$. Maximum percentage of shooting $(81.67 \%)$ with the maximum mean value for number of shoots (7.56) and shoot length (7.07) occurred when the fresh shoot tip of $C$. tuberculata were planted on to MS salts containing $2 \mathrm{mg} / \mathrm{L}$ of BAP, $0.5 \mathrm{mg} / \mathrm{L}$ of NAA and 0.25 $\mathrm{mg} / \mathrm{L}$ of Kin. The new shoots were then inoculated on $1 / 2$ strength MS salts fortified with NAA and IBA root induction. The highest rooting percentage $(61.67 \%)$, as well as root length $(3.4 \mathrm{~cm})$ was obtained with $0.5 \mathrm{mg} / \mathrm{L}$ of both IBA and NAA. The current study could be beneficial for providing the basis to restore wild populations of $C$. tuberculata using in-vitro raised mass propagated plants, and help conserve the endangered germs of hills.

Received | October 14, 2021; Accepted | December 30, 2021; Published | January 11, 2022

*Correspondence | Shakeel Ahmad Jatoi, Bio Resources Conservation Institute, NARC, Islamabad, Pakistan; Email: sajatoi@gmail.com Citation | Taqi, M., S. Erum, S. Rasheed, S.U. Siddiqui and S.A. Jatoi. 2021. In-Vitro Propagation for Conserving the Gems of the Hills Caralluma tuberculata to Rescue the Valuable Endangered Medicinally Important Plant. Pakistan Journal of Agricultural Research, 34(4): 868-877.

DOI | https://dx.doi.org/10.17582/journal.pjar/2021/34.4.868.877

Keywords | Plant growth regulator, Protocol, In-vitro, C. tuberculata, Chungan

\section{Introduction}

G ems of the hills (C. tuberculata), is a perennial succulent branched herb, of the family Asclepiadaceae. More than 2000 species belong to this family are found in subtropical and tropical African regions, South-America and also in Southeastern and Northern Asia (Rehman et al., 2014). In Pakistan, $C$. tuberculata is growing, as a wild species in the hills of Suleman, that extends over Baluchistan, Punjab and Khyber Pakhtunkhwa. It is mainly used as a vegetable and people collect it from the hills of Zhob,
Waziristan (south), Buner and from other dry regions of Pakistan (A1-Massarani et al., 2012). C. tuberculata production is non-cultivated in Pakistan, so it is not easily available and is quite expensive. (Rehman et al., 2014). Locally C. tuberculata is also known as Pamanghi, Aputag, Marmut and Boteri. Pamankay/ Pamanay in Pashtun belt and Chunga in Saraiki and Punjab region (Basheer et al., 2014). The plant has been frequently used for its therapeutic properties for treating many diseases like diabetes, weight loss and cancer especially for the treatment of breast cancer. Particularly Anti-tumor and anti-cancer activities December 2021 | Volume 34 | Issue 4 | Page 868 
have been found in pregnane glycosides of C. tuberculata, while it is structural similarity to estrogenic agonists, it also reduces the sugar level (Waheed et al., 2011; A1-Harbi et al., 1994). The bitter succulent juicy stem of $C$. tuberculata is mainly used as a vegetable either alone or with meat or eaten raw; is used as astringent tonic, febrifuge, improve stomach function and useful in joint pain. (Shinwari et al., 2010). This plant is also famous for containing terpenes (amyrin, $\alpha$ amyrin acetate, lupeol, $\alpha$ and $\beta$ and $\alpha$ amyrin cinnamate), sterols (taraxasterol, $\beta$-sitosterol and its different glucosides), caratubersides, flavonoids, as well as some bioactive secondary compounds including amino acids, terpenoids and tannins, reducing sugars, beta cyanins and steroids (Adnan et al., 2014; Waheed et al., 2011).

As its natural production mainly confined to mountains, the mature up-rooted plants come to the local market through collectors. These are then transported to the big cities and other faraway areas from these local markets. It is considered to be sciophytes and during past few years, its population has decreased severely, which might be due to indiscriminatory over harvesting of the plants along with roots as well as cutting of trees and shrubs in the mountainous areas that provides protection and shade to it. Contrary to the reduced availability the increased demand from expanding population is making its existence most challenging. That is the main reason that C. tuberculata, which was found in abundance before cannot be found easily now. People travel far in the mountains for its search (Rehman et al., 2014). No systematic efforts have been made yet to bring it under cultivation for commercial use. Over grazing by the animals is also putting more pressure on its population. Several studies have already highlighted this issue and stressed the need to protect this valuable plant from complete extinction (Rehman et al., 2014).

It has been observed since last decade that over-harvesting pressure is posing the danger of its genetic erosion. Most of the wild populations have been disappeared as local inhabitants are uprooting complete plants. Emphasis needs to be made for replantation of this plant to revive it populations. Commercial scale plantation of this plant can reduce over-harvesting pressure of natural populations. C. tuberculata can be grown throughout the year, however, summer season is more conducive for its fast growth. C. tuberculata can be propagated by cutting, using any plant part having node. It can tolerate drought condition and water requirement is quite low. It remains happy in shady places. C. tuberculata can be grown directly in field without transplanting from nursery, however successful crops can be acquired by raising nursery and then transplanting it to the open field.

Tissue culture could be a suitable way to raise $C$. $t u$ berculata nursery for large scale production. Keeping in view the critical state of this plant-species, a study to investigate the response of $C$. tuberculata against diverse PGRs and optimize conditions for its mass-propagation, thus making it available for conservation and restoring its wild populations.

\section{Materials and Methods}

\section{Plant material}

The germplasm of C. tuberculata for the study was provided by vegetable program Agriculture Research Institute (ARI), Tarnab, Peshawar, Pakistan. Plant material were sown under glass house in pots at BCI, NARC Islamabad, for continues supply of ex-plants for lab work.

\section{Surface sterilization of explants}

Ex-plants, comprising nodal-tips, washed for 30 minutes under tap water and treated with Tween- 20 (detergent) 3-5\% (v/v) and for 2-5 minutes after surface sterilized with $0.01 \%(\mathrm{v} / \mathrm{v}) \mathrm{HgCl}_{2}$ rinsing with distilled water. Explants were treated with $1 \mathrm{gm} / \mathrm{L}$ Fungicide for 30 to 60 seconds. Explants were then washed with sterile double distilled water (6-8 times) and subsequently cut into suitable size and inoculated on MS medium (Murashige and Skoog, 1962) under laminar flow hood surface disinfected with $70 \%$ alcohol. For sterilization, MS medium was autoclaved at $121^{\circ} \mathrm{C}$ for 15 minutes whereas culturing tools were exposed to UV light (15-20 minutes) after autoclaving.

\section{Culture media and condition}

The explants were inoculated on to MS basal salts (Murashige and Skoog, 1962) supplemented with different types and concentrations of PGRs. Different categories of plant growth regulators mainly BAP, NAA, 2,4-D, IBA, GA 3 and Kin either alone or in diverse combinations were used. The media contained $3 \%(\mathrm{w} / \mathrm{v})$ sucrose having $\mathrm{pH}$ adjusted to $5.8 \pm 1$ before putting agar. The medium was then autoclaved at 121 ${ }^{\circ} \mathrm{C}$ for 15-20 minutes. Incubation of the cultured ex- 
plants was conducted at $20 \pm 2^{\circ} \mathrm{C}$ with $16 / 8$ hours light and $\pm 75 \%$ relative humidity.

\section{Callus morphology and growth response (\%)}

Callogenesis, in response to different PGRs used, from nodal explants was recorded from each replication and this data was used to calculate percentage. Predominant color and texture of the calli was recorded for all the cultures tubes having explants with callus induction.

\section{Shoot induction and root growth Response (\%)}

Shoot and root growth responses were recorded from each cultured nodal explant against various PGRs used and then percentage was calculated. Number of shoots and roots per culture as well as their length (mm) were recorded.

\section{Statistical analysis}

Each treatment was replicated 10 times following arrangements as per completely randomized design. Least significant differences (LSD) were computed. Statistical analysis was carried out using statistix 8.1.

Table 1: Analysis of variance for callus growth response (\%) in C. tuberculata.

$\begin{array}{lllllll}\text { Treatments } & \text { Source } & \text { DF SS } & \text { MS } & \text { F } & \text { P } \\ \text { 2,4-D alone } & \text { Levels } & 4 & 7510.00 & 1877.50 & 38.8 & 0.0000 \\ & \text { Error } & 10 & 483.33 & 48.33 & & \\ \text { 2,4-D + BAP } & \text { Levels } & 4 & 3443.60 & 860.900 & 43.6 & 0.0000 \\ & \text { Error } & 10 & 197.33 & 19.733 & & \\ 2,4-D+\text { Kin } & \text { Levels } & 4 & 1356.67 & 339.167 & 20.4 & 0.0000 \\ & \text { Error } & 10 & 166.67 & 16.667 & & \\ \text { BAP+NAA+Kin } & \text { Levels } & 4 & 9668.75 & 2417.19 & 213 & 0.0000 \\ & \text { Error } & 10 & 125.00 & 11.36 & & \end{array}$

\section{Results and Discussion}

\section{Response of callus growth (\%)}

The callus growth response (\%) in C. tuberculata, revealed significant differences for different PGRs used in this study (Table 1). Callogenesis recorded at 2,4$\mathrm{D}$ alone revealed an increasing trend upto $2 \mathrm{mg} / \mathrm{L}$ where callus induction was $65 \%$, however, with the further addition in 2,4-D affected negatively displaying reduction in callus induction (Figure 1A). The pattern of callus induction did not depict any trend with the increasing levels of 2,4-D plus fixed dose of BAP (Figure 1B). At these combinations the highest rate of callus induction was $47 \%$ that was displayed at a combination of 2,4-D and BAP at $2 \mathrm{mg} / \mathrm{L}$ and 1 $\mathrm{mg} / \mathrm{L}$, respectively. Callogenesis was quite poor when different levels of $2,4-\mathrm{D}$ with $1 \mathrm{mg} / \mathrm{L}$ of Kin was used (Figure 1C). The highest callus induction rate $(28.3 \%)$ in this case was recorded on $0.5 \mathrm{mg} / \mathrm{L}$ of both PGR used. The simultaneous use of NAA $(0.5-2 \mathrm{mg} /$ $\mathrm{L})$ with a constant dose of BAP $(2 \mathrm{mg} / \mathrm{L})$ and Kin $(0.25 \mathrm{mg} / \mathrm{L})$ revealed increasing trend up to NAA of $(1 \mathrm{mg} / \mathrm{L})$ whereas further increment in the dose resulted in decline in callus induction (Figure 1D). After 27 days, the highest callus induction (78.33\%) was noted in MS basal salts having NAA $(2.0 \mathrm{mg} / \mathrm{L})$, BAP $(1.0 \mathrm{mg} / \mathrm{L}) \& \mathrm{Kin}(0.25 \mathrm{mg} / \mathrm{L})$. It was followed $(65 \%)$ on medium enriched with $2,4-\mathrm{D}(2.0 \mathrm{mg} / \mathrm{L})$. Minimum induction of callus (6.67\%) was recorded at $2,4-\mathrm{D}(2.0 \mathrm{mg} / \mathrm{L})$ plus Kin $(2.0 \mathrm{mg} / \mathrm{L})$. On all sets of treatments, when shoot apex was grown on simple MS basal salts (control), there was no callus formation. The percent callus initiation was different in all combination and concentration of those PGRs. At a certain concentration of each PGR, maximum growth result was obtained. When the concentration was increased beyond that level of concentration, growth rate decreased. (Rehman et al., 2014) also mentioned that when Cytokinin (BA) were included with 2,4-D, the callus production of $C$. tuberculata accelerated; while in the current study when Cytokinin (BAP) was used with $2,4-\mathrm{D}$, the callus production was decreased. In this investigation, when an optimum concentration of NAA was applied with BAP and Kin, the callus production accelerated. This result was somewhat found to be in harmony with (Rashid et al., 2009) with the combined use of 2,4-D and Kin on nodal segments of C. duffusa. Ramadevi et al. (2012) reported that best callus production can be achieved from the combination of auxin and cytokinin.

\section{Morphological characteristics of callus}

Morphology of callus was observed visually. Color of the callus was greenish brown when 2,4-D was applied alone while callus produced by $\mathrm{BAP}+\mathrm{NAA}+\mathrm{Kin}$ had a whitish brown color. The medium containing 2,4-D+BAP and 2,4-D+kin produced callus with pale yellow color (Figure 2). Pale yellow to brown, callus was formed under the various combinations of 2,4-D, BAP, NAA but kinetin produced compact and friable callus in C. tuberculata cultures Robert et al. (2012). When 2,4-D used in low concentration, it produced pale green and friable callus, while high dose of 2,4-D produced green and compact callus in C. tuberculata. Lower concentration of 2,4-D gives 
negative results (Sreelatha et al., 2009). MS Media with different concentrations of BAP, NAA and Kin produced compact callus while medium supplemented with 2,4-D alone and in combination with other plant growth regulators, produced granular to semi compact callus in C. tuberculata. Rehman et al. (2014) also observed granular callus produced from $2,4-\mathrm{D}$ in C. tuberculata.
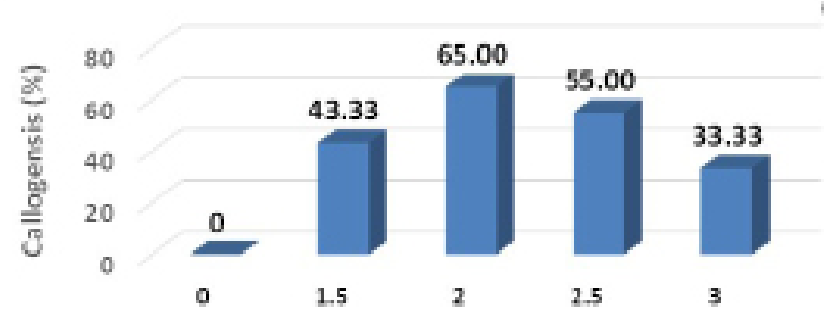

(2,4-D mg/L)

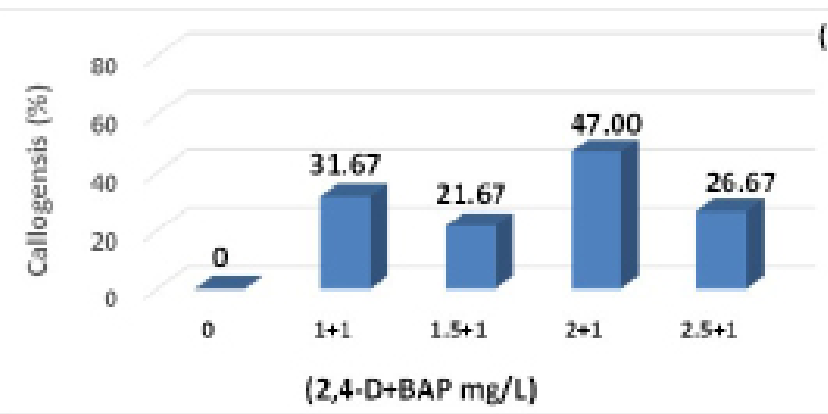

(C)
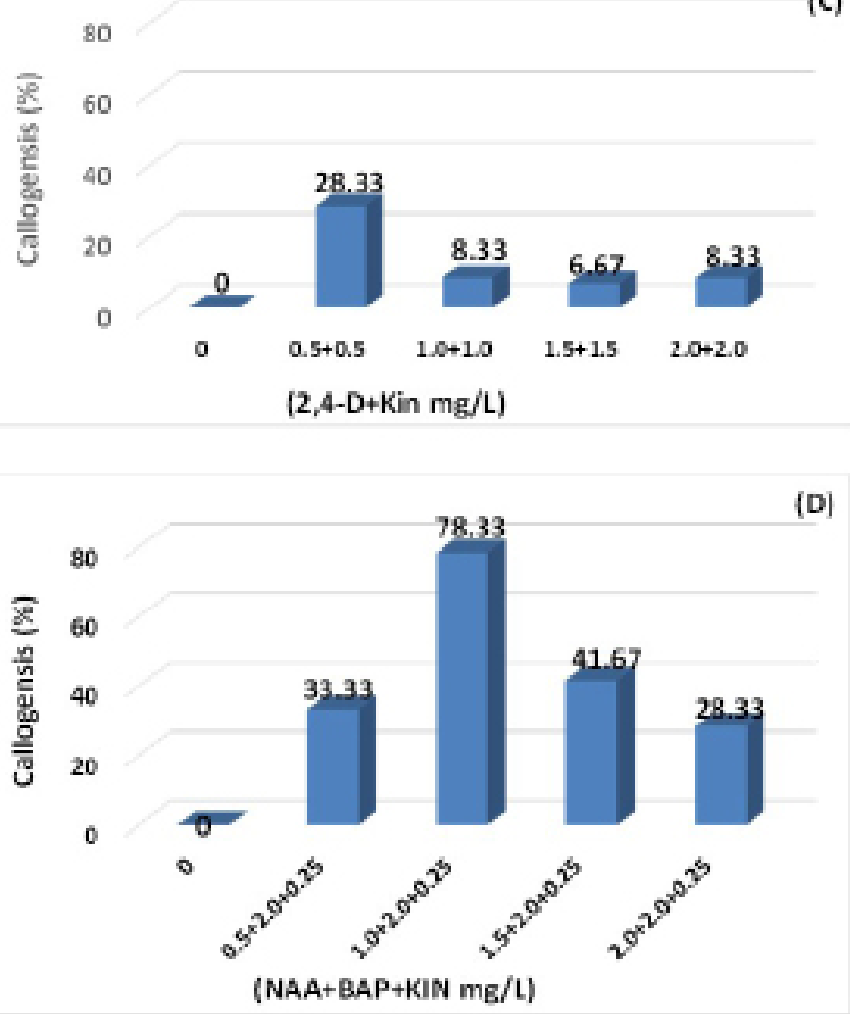

Figure 1: Response of different concerntration of different plant growth regulators on callus induction in Carraluma tuberculata; $\mathbf{A})$ 2,4-D alone, B) 2,4-D+BAP, C) 2,4-D+Kin, D) $B A P+N A A+K I N$.

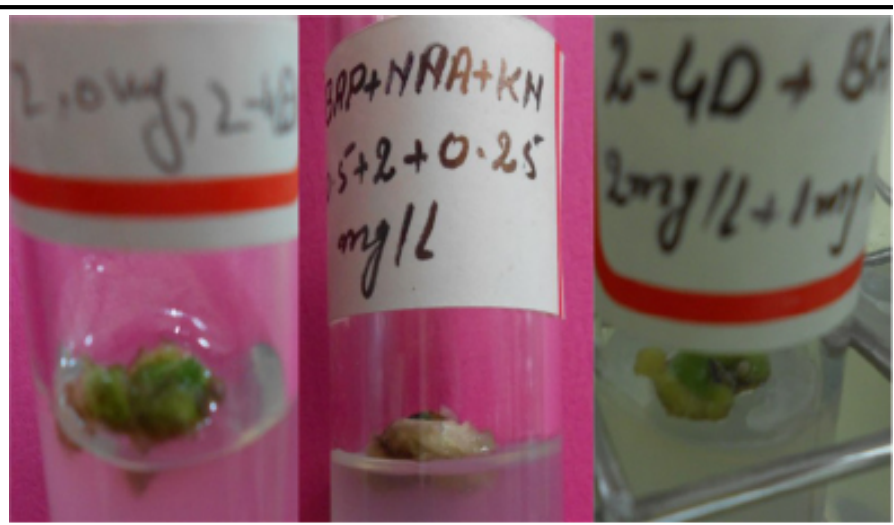

Figure 2: Morphological characteristics of callus observed during in-vitro propagation of Caralluma tuberculate against different PGR supplemented to MS-medium.

Table 2: Analysis of variance for shoot growth response (\%) in C. tuberculata.

\begin{tabular}{lllllll} 
Treatments & \multicolumn{2}{l}{ Source } & DF SS & MS & F & P \\
BAP & Levels & 4 & 2240.00 & 560.000 & 67.2 & 0.0000 \\
& Error & 10 & 83.33 & 8.333 & \\
Kin & Levels & 4 & 960.00 & 240.000 & 13.1 & 0.0006 \\
& Error & 10 & 183.33 & 18.333 & \\
GA $_{3}$ & Levels & 4 & 2760.00 & 690.000 & 51.7 & 0.0000 \\
BAP + Kin & Error & 10 & 133.33 & 13.333 & \\
& Levels & 4 & 4576.67 & 1144.17 & 137 & 0.0000 \\
BAP+NAA+Kin & Levels & 4 & 7210.00 & 1802.50 & 216 & 0.0000 \\
& Error & 10 & 83.33 & 8.33 & &
\end{tabular}

Shoot growth response (\%)

Shoot proliferation (\%) revealed significant differences in C. tuberculata for various plant growth regulators used in this study (Table 2). BAP alone has shown increase in shoot induction when its concentration was raised to $2.5 \mathrm{mg} / \mathrm{L}$ and further increment in BAP level reflected a decline in shoot induction (Figure $3 \mathrm{~A}$ ). The maximum shoot induction rate observed at BAP supplemented medium was $73.3 \%$ at $2.5 \mathrm{mg}$ BAP/L. The shoot induction was also recorded at control (41.67\%) that also remained at par with the shoots induced at highest BAP level $(3.5 \mathrm{mg} / \mathrm{L})$. In case of Kinetin enriched media, with the increase in Kin concentrations from $1.5 \mathrm{mg} / \mathrm{L}$ to $3 \mathrm{mg} / \mathrm{L}$, a decline in shoot induction rate from $41.67 \%$ to $23.3 \%$ was recorded (Figure 3B). A similar declining trend was also revealed on $\mathrm{GA}_{3}, \mathrm{BAP}+\mathrm{Kin}$ and $\mathrm{BAP}+\mathrm{NAA}+\mathrm{Kin}$ supplemented MS medium (Figure 3C, D andE).

Maximum shoot induction (81.67\%) was recorded with $2 \mathrm{mg} / \mathrm{L}$ of BAP in addition to NAA $(0.5 \mathrm{mg} / \mathrm{L})$ and $\operatorname{Kin}(0.25 \mathrm{mg} / \mathrm{L})$ that was followed by shoot 
growth (73.33\%) in MS medium fortified by BAP with $(2.5 \mathrm{mg} / \mathrm{L})$ alone. The minimum shoot response (16.67\%) was observed in BAP+Kin $2.5 \mathrm{mg} / \mathrm{L}$ each.

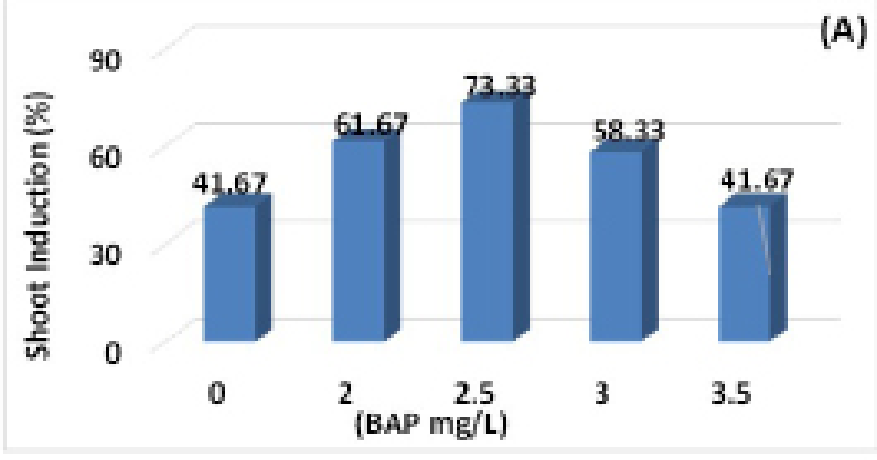

(B)

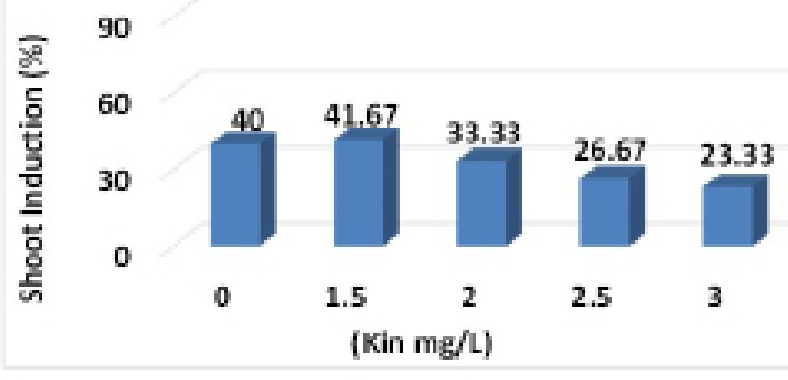

(C)
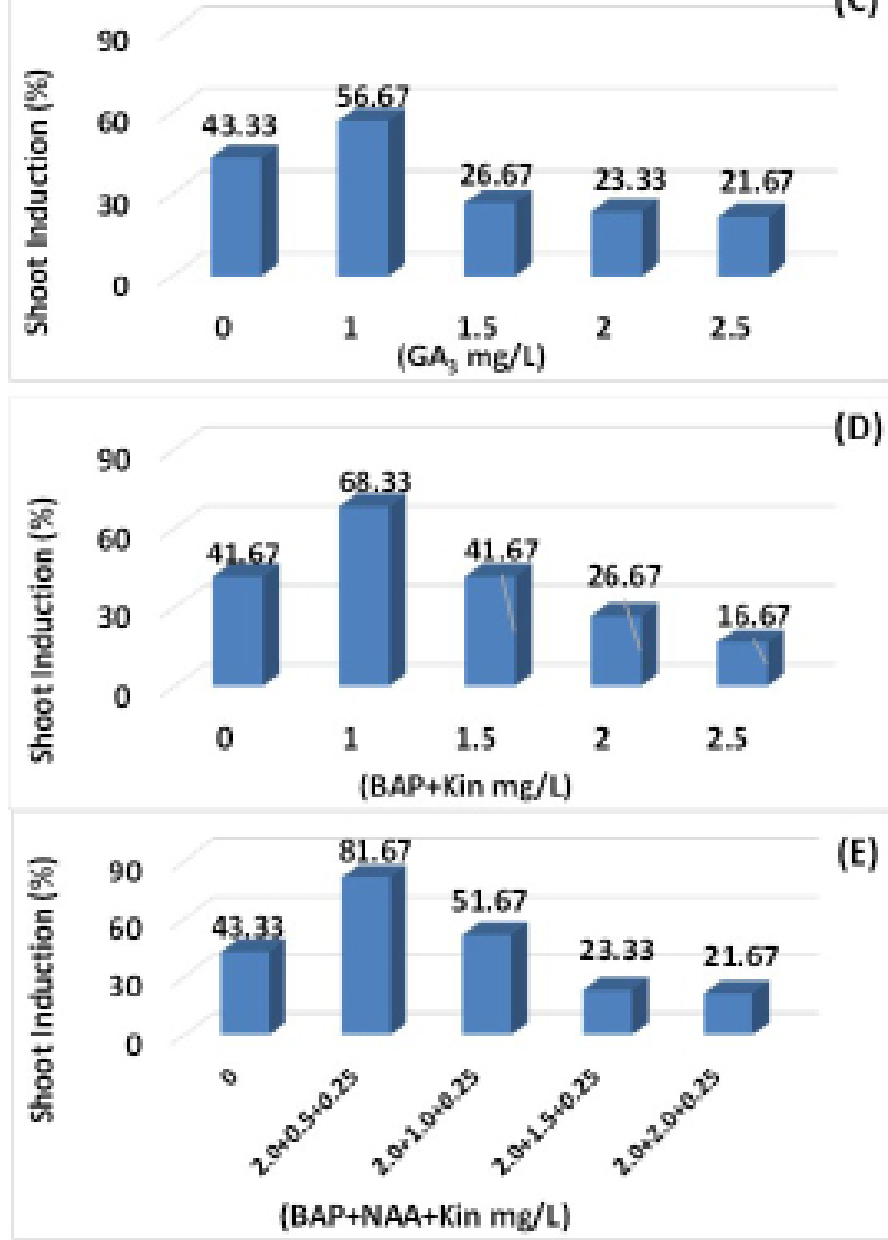

Figure 3: Shoot induction in Carraluma tuberculata against different concentration of different plant growth regulators; A) $B A P$ $m g / L$, B) $K i n m g / L$. C) $G A_{3} m g / L$, D) $B A P+K I N m g / L$, E) $B A P+N A A+K i n m g / L$.
Different studies conducted on shoot organogenesis from callus and direct organogenesis was reviewed to support the current investigations; Although Thomas et al. (2009) reported organogenesis in C. diffusa, maximum shooting response (82.4\%) was recorded in MS medium containing BAP+Kin+NAA. The finding reported by Aruna et al. (2012) also showed maximum shoot (89.4\%) formation at $2.5 \mathrm{mg} / \mathrm{L}$ of BAP. The maximum shoot induction in $C$. tuberculata was (90\%), when 1.5 and $0.5 \mathrm{mg} / \mathrm{L}$ of BAP and NAA, respectively was added to MS medium (Kalimuthu et al., 2014). It was also observed by Aruna et al. (2012) that among varying levels of BAP from 0.5 to 3 $\mathrm{mg} / \mathrm{L}$, only 0.5 to $2.5 \mathrm{mg} / \mathrm{L}$ showed positive response on shooting in C. tuberculata cultures. MS basal salts enriched with $2 \mathrm{mg} / \mathrm{L}$ of BA showed highest rate of shoot induction in C. tuberculata (83\%) and Kin gave least growth response of shoot, which was $56 \%$. Best shoot growth response percentage was $90-95 \%$ in C. tuberculata at various concentrations of cytokinin and auxin. Sreelatha et al. (2009) also observed shoot growth response of $C$. tuberculata (65\%) at combined dose of $1,0.5$ and $0.5 \mathrm{mg} / \mathrm{L}$ of BAP, NAA, Kin, respectively. Shooting frequency of $90 \%$ was obtained when Stevia was grown on medium fortified with 1 $\mathrm{mg} / \mathrm{L}$ of BAP (Kalimuthu et al., 2013).

\section{Number of shoots per culture}

The maximum shoots $(7.56 \pm 0.58)$ were recorded at combination of $2,0.5$ and $0.25 \mathrm{mg} / \mathrm{L}$ of BAP, NAA and Kin, respectively, and it was followed by shoot number (6.89) in MS medium fortified by BAP (2.5 $\mathrm{mg} / \mathrm{L})$ alone whereas the minimum shoots (1.22) were observed at $3.0 \mathrm{mg} / \mathrm{L}$ of Kin (Figure 4).

Fresh shoot tips of C. tuberculata were grown on MS basal salts containing different levels of BAP, Kin, GA alone, and in combinations with Kin, BAP and NAA concentrations for shoot initiation. Shoot sprouting was started after a week of culturing the ex-plant. However, the sprouting efficiency was distinct in medium fortified with different plant growth regulators and their different concentrations. When BAP alone was used, positive results were obtained in almost all concentrations. In BAP $(2.0 \mathrm{mg} / \mathrm{L})$, maximum shoots were recorded, that slowly declined with the increase in concentration of BAP (Figure 7). It was also observed by Aruna et al. (2012), when only BAP from 0.5 to $2.5 \mathrm{mg} / \mathrm{L}$ was used, better results were obtained at certain optimum concentration. The current investigations also depicted that single use Kin alone re- 
sulted in quite fewer shoots as compared to rest of PGR. Addition of auxin (NAA) with an optimum concentration of two cytokinin members (BAP and Kin) significantly increased the shoot formation of $C$. tuberculata. Sreelatha et al. (2009) reported that the application of NAA along with Cytokinin resulted in more shoot formation of $C$. tuberculata cultures. He also reported that the use of kinetin alone resulted in poor shooting of $C$. diffusa. In the present study when $\mathrm{GA}_{3}(1 \mathrm{mg} / \mathrm{L})$ alone was used, maximum shoots (3.89) were obtained; interestingly, some plants were also observed with roots in medium fortified with GA3. The combination of BAP \& Kin also gave response towards shoot sprouting, maximum shoots (4.0) were observed in medium containing I $\mathrm{mg} / \mathrm{L}$ of both BAP and Kin.

\section{Mean shoot length (cm)}

Remarkable effect of PGRs have been observed on the shoot length in C. tuberculata (Figure 4). The longest shoot $(7.07 \pm 0.7 \mathrm{~cm})$ was observed on MS salts enriched with BAP $(2 \mathrm{mg} / \mathrm{L})+\operatorname{Kin}(0.25 \mathrm{mg} / \mathrm{L})+-$ NAA $(0.5 \mathrm{mg} / \mathrm{L})$. It was followed by shoot length $(5.67 \pm 1.09 \mathrm{~cm})$ in MS medium containing $2.5 \mathrm{mg} / \mathrm{L}$ of BAP whereas, minimum length of shoot $(0.8 \pm 0.1$ $\mathrm{cm}$ ) was noted at $3 \mathrm{mg} / \mathrm{L}$ of Kin.

C. tuberculata when inoculated on MS medium containing BAP alone produced positive results on shoot length in all concentrations. In case of BAP used alone maximum shoot length $(5.67 \mathrm{~cm})$ was recorded on BAP $(2.5 \mathrm{mg} / \mathrm{L})$, the shoot length decreased gradually with the increasing levels of BAP. Minimum shoot length $(1.67 \mathrm{~cm})$ was observed on medium containing higher levels of BAP $(3.5 \mathrm{mg} / \mathrm{L})$. In general, the shoot length on medium containing kinetin and $\mathrm{GA}_{3}$ alone were also low. The longest shoot (2.17 $\mathrm{cm})$ at $1.5 \mathrm{mg} / \mathrm{L}$ of kinetin, while medium containing $1 \mathrm{mg} / \mathrm{L}$ of $\mathrm{GA}_{3}$ also produced the longest shoot $(2.75 \mathrm{~cm})$. When different combinations of BAP-Kin it was noted that the overall the longest shoot (3.57 $\mathrm{cm})$ was observed on MS medium containing different concentration of $\mathrm{BAP}+\mathrm{Kin}$, while addition of NAA (BAP-NAA-Kin) accelerated the shoot length to $7.07 \mathrm{~cm}$. Ramadevi et al. (2012) explained that maximum number of shoots (5.16) per explants of $C$. tuberculata with average shoot length $(2.9 \mathrm{~cm})$ were recorded when $2 \mathrm{mg} / \mathrm{L}$ of $\mathrm{BA}$ and $0.5 \mathrm{mg} / \mathrm{L}$ of $2 \mathrm{iP}$ were applied in combination. Similarly, Phulwaria et al. (2013) revealed that the MS medium enriched with BAP promoted shoot length in Stevia. Kiranmai et al. (2015) reported that optimal concentration of BAP and NAA produced shoot-let with shoot length of $5.6 \mathrm{~cm}$ in C. tuberculata.

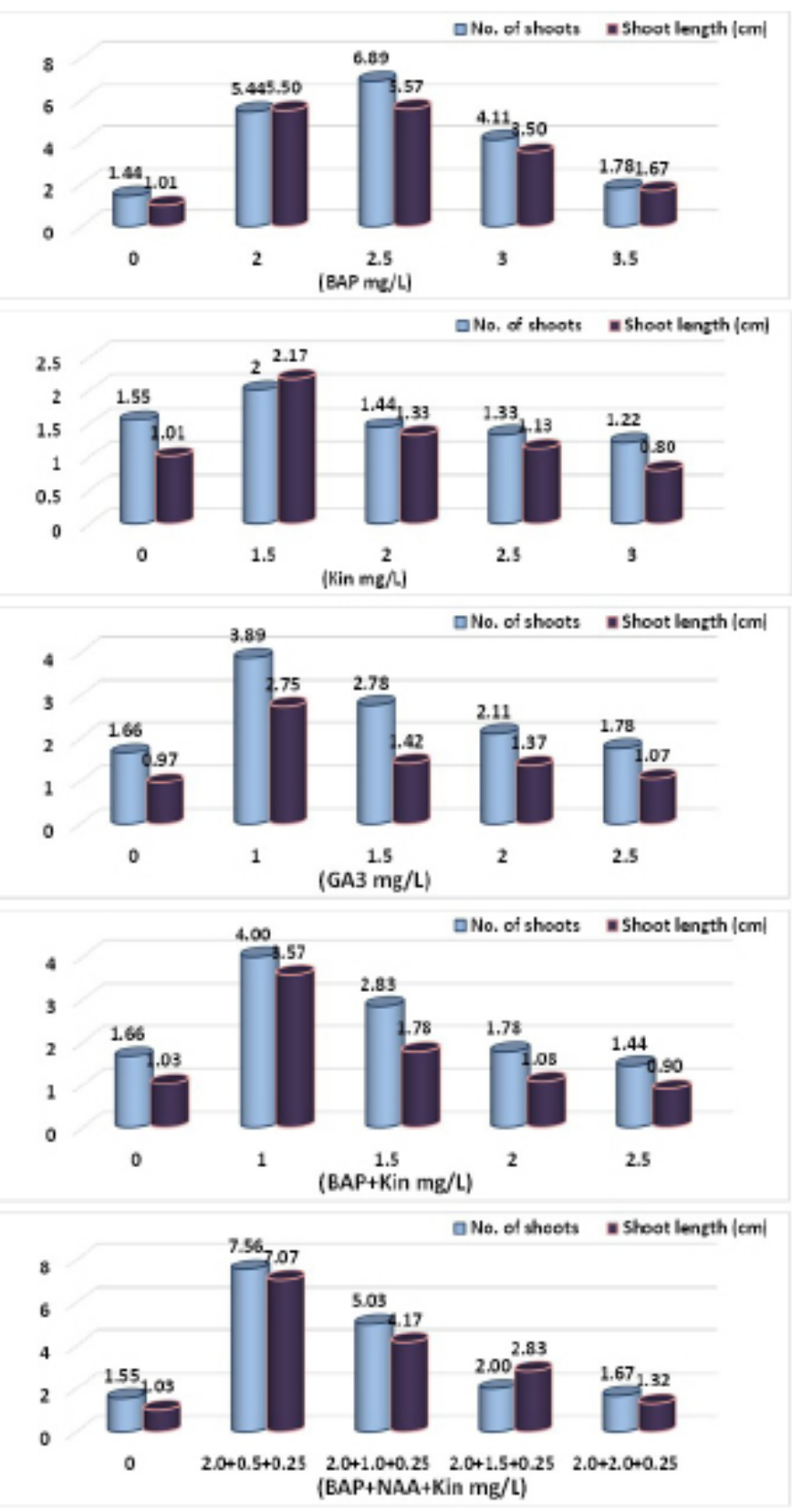

Figure 4: Number of shoots and shoot length $(\mathrm{cm})$ in Carraluma tuberculata against different concentration of different plant growth regulators; A) $B A P m g / L$, B) $K i n m g / L$, C) $G A_{3} m g / L$, D) $B A P+K I N m g / L$, E) $B A P+N A A+K i n m g / L$.

\section{Root growth response (\%)}

Root induction rate was negatively affected with the increasing levels of IBA from 0.5 to $2.0 \mathrm{mg} / \mathrm{L}$ keeping concentration of NAA constant. Similarly, rooting was decreased with the increasing level of NAA and keeping IBA constant (Figure 5). The best response for root sprout $(61.67 \%)$ was recorded at 0.5 $\mathrm{mg} / \mathrm{L}$ of both IBA and NAA, followed by root sprout (46.67\%) in medium containing $1 \mathrm{mg} / \mathrm{L}$ of NAA and $0.5 \mathrm{mg} / \mathrm{L}$ of IBA. The minimum rooting response 
(23.33\%) was observed at a combination of IBA at the rate of $2 \mathrm{mg} / \mathrm{L}$ and NAA at the rate of $0.5 \mathrm{mg} / \mathrm{L}$.

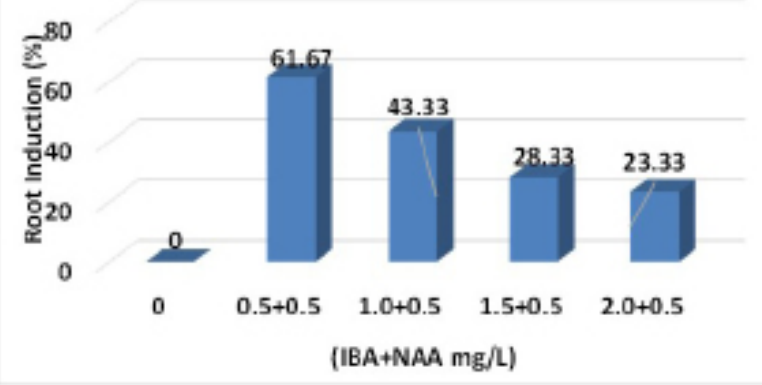

(A)

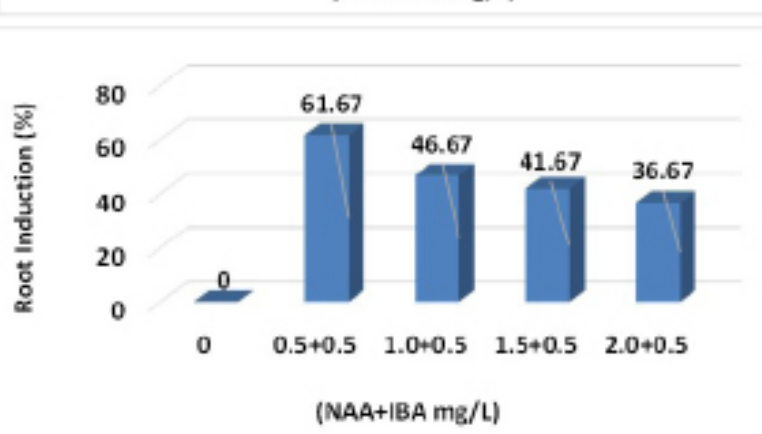

(B)

Figure 5: Root induction in Carraluma tuberculata against different concentration of A) $I B A+N A A, \mathbf{B}) N A A+I B A$.

Established shoots were sub-cultured on half strengthen MS medium for rooting. Different studies conducted on roots establishment was reviewed to support the current study. Karthik et al. (2013) reported that when shoots of $C$. tuberculata were inculcated on half strengthen MS salts having varying concentrations of IBA and NAA. The highest rooting response (90.33\%) for C. tuberculata was observed when an optimal levels of NAA added to half strength MS medium (Kalimuthu et al., 2014). Among the various auxins that were added to half strengthen MS salts, NAA was found to be most effective for induction of roots in C. tuberculata (Ramadevi et al., 2012). Maximum rooting (75\%) was recorded in C. tuberculata when grown on MS salts, enriched with NAA (Sreelatha et al., 2009). The highest rate of rooting (78.06\%) was obtained at $0.5 \mathrm{mg} / \mathrm{L}$ of both IBA and IAA in root establishment of C. tuberculata (Ugraiah et al., 2011).

\section{Number of roots per culture}

A significant response was observed on number of roots initiated when different levels of IBA and NAA were applied. The maximum roots (4.34) were induced when concentration of both NAA and IBA was kept $0.5 \mathrm{mg} / \mathrm{L}$.It was followed by number of roots $(2.55)$ on 1.0 and $0.5 \mathrm{mg}$ of NAA and IBA, respectively (Figure 6). Minimum number of roots (1.44) was achieved on medium applying $2 \mathrm{mg} / \mathrm{L}$ IBA and $0.5 \mathrm{mg} / \mathrm{L} \mathrm{NAA}$.

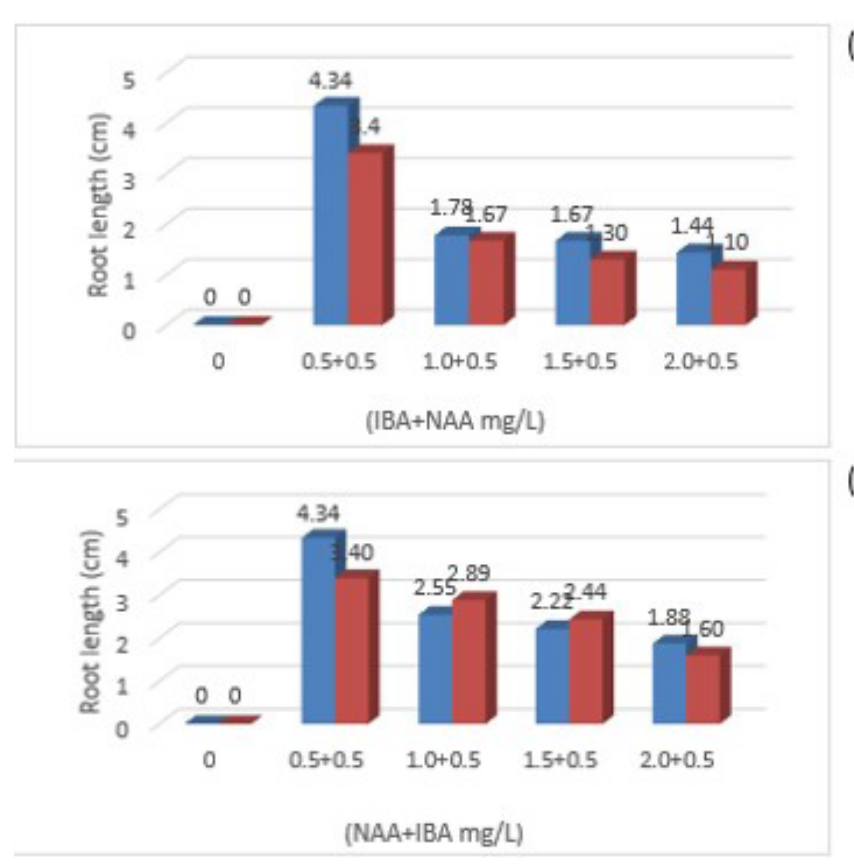

(A)

Figure 6: Number of roots and root length recorded in Carraluma tuberculate against different concentration of $\mathbf{A}) I B A+N A A, \mathbf{B})$ $N A A+I B A$.

Rooting of C. tuberculata cultures were started after two weeks, the shoots that regenerated were cultured on different concentration of IBA and NAA, showed significant differences in results. In one combination, IBA was kept constant at $0.5 \mathrm{mg} / \mathrm{L}$ and NAA increasing with an interval of $0.5 \mathrm{mg} / \mathrm{L}$, while in other combination the arrangement was vice versa that revealed divergent results. The maximum rooting was obtained at $0.5 \mathrm{mg} / \mathrm{L}$ of both auxins. Similar finding was revealed by (Karthik et al., 2013) in C. tuberculata where they also found the highest number of roots on same concentrations. Aruna et al. (2012) successfully increased number of roots and reduced the time for rooting when NAA was added to half strength MS basal salts in different intensities. They obtained the highest number of roots were at $1 \mathrm{mg} / \mathrm{L}$ of NAA. In a similar study, half strengthen medium fortified with NAA appeared to be most effective for rooting in $C$. tuberculata cultures (Ramadevi et al. 2012). Another report displayed $0.5 \mathrm{mg} / \mathrm{L}$ of NAA to be very efficacious for inducing roots in C. tuberculata (Sreelatha et al., 2009).

\section{Mean root length $(\mathrm{cm})$}

In both the cases with either NAA or IBA, their combination yielded decline in root length with the increase in levels of both IBA and NAA (Figure 6). The longest root $(3.4 \mathrm{~cm})$ was achieved on medium added with $0.5 \mathrm{mg} / \mathrm{L}$ of both NAA and IBA, followed by root length $(2.89 \mathrm{~cm})$ at $1.0 \mathrm{mg} / \mathrm{L}$ of NAA 
and $0.5 \mathrm{mg} / \mathrm{L}$ of IBA. The shortest root with $1.1 \mathrm{~cm}$ length was displayed at IBA $(2.0 \mathrm{mg} / \mathrm{L})$ in combination with $0.5 \mathrm{mg} / \mathrm{L}$ of NAA.

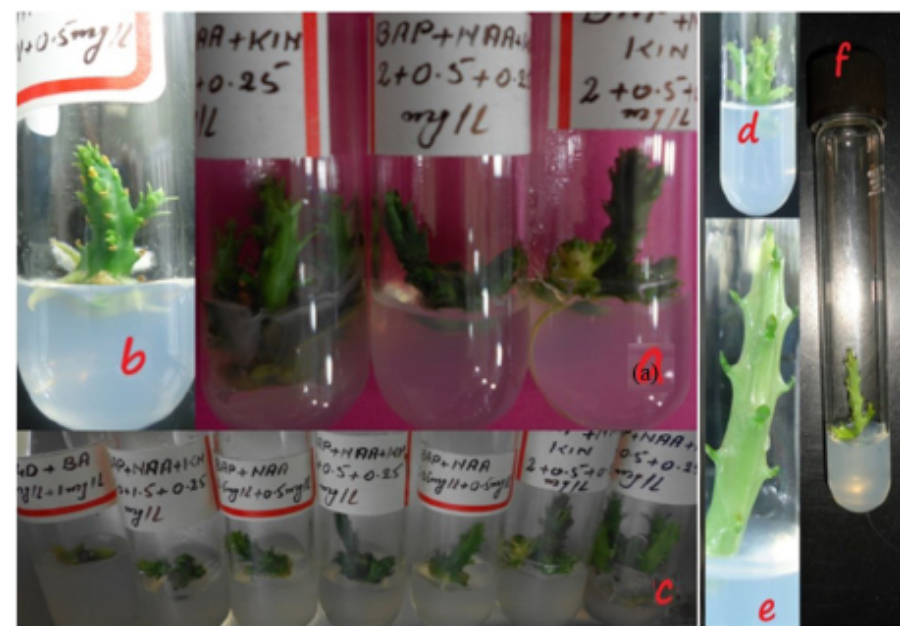

Figure 7: Different stages of multiple shoot formation of medium containing $B A P+N A A+K i n$ ( $a$ and $b$ ), variation in shoot length of $C$ tuberculata $(b, c, e, f)$.

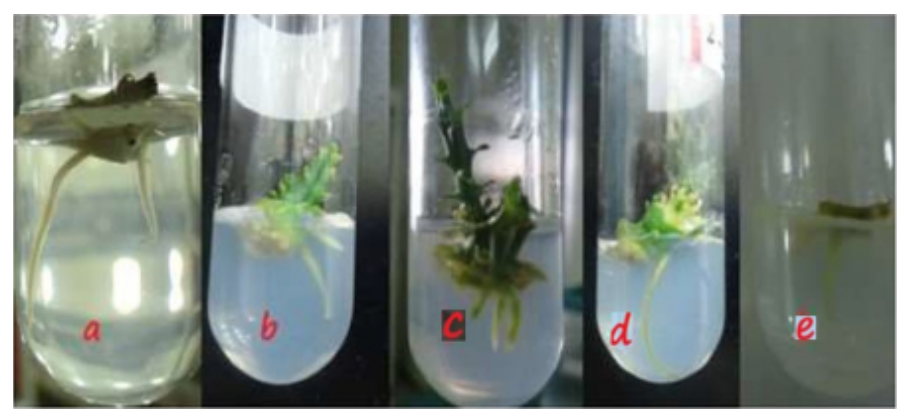

Figure 8: Root morphology observed in Carraluma tuberculata; A) $I B A(1 \mathrm{mg} / \mathrm{L})+N A A 0.5 \mathrm{mg} / \mathrm{L}, \mathbf{B}$ and D) $(1.5 \mathrm{mg} / \mathrm{L})+N A A 0.5$ $m g / L$, C) $N A A(1 m g / L)+I B A 0.5 m g / L$, E) $N A A(2 m g / L)+I B A$ $0.5 \mathrm{mg} / \mathrm{L}$

Kalimuthu et al. (2013) while working on C. diffusa found the maximum root length at $0.5 \mathrm{mg} / \mathrm{L}$ of both NAA and IBA. In another study, $4.09 \mathrm{~cm}$ long roots were achieved at half strengthen MS salts when added with IBA $0.5 \mathrm{mg} / \mathrm{L}$ in C. tuberculata (Sreelatha et al., 2009). Mean root length $(1.7 \mathrm{~cm})$ in C. tuberculata has also been reported by adding $0.5 \mathrm{mg} / \mathrm{L}$ of IAA to MS salts (Muthukrishnan et al., 2015). Komalavalli et al. (2000) achieved maximum root length $(2.9 \mathrm{~cm})$ on MS medium with the addition of $2.0 \mathrm{mg} / \mathrm{L}$ of IAA.

\section{Root morphology}

Morphological characteristics of roots for different PGRs were observed at varying levels of IBA and NAA as well as at their different combinations. Present findings revealed that NAA and IBA with a similar ratio of $0.5 \mathrm{mg} / \mathrm{L}$ produced thick roots as compared to concentration of IBA $(1.0-2.5 \mathrm{mg} / \mathrm{L})$ with $0.5 \mathrm{mg} / \mathrm{L}$ of NAA that yielded thin and long roots
(Figure 8). Our finding is also more or less similar to results reported by Kalimuthu et al. (2013) while working on Caralluma diffusa.

\section{Conclusion and Recommendations}

A direct tool for micro-propagation was established for a valuable endangered and medicinally important plant C. tuberculata. Best callus induction and growth response was observed in fresh shoot tip inoculated in MS salts added with BAP + NAA + Kin with the concentration of 1,2 , and $0.25 \mathrm{mg} / \mathrm{L}$, respectively. Significant variation in shoot response was observed and the medium enriched with BAP $(2.0 \mathrm{mg} / \mathrm{L})+\mathrm{NAA}$ $(0.5 \mathrm{mg} / \mathrm{L})+\operatorname{Kin}(0.25 \mathrm{mg} / \mathrm{L})$ was recorded with the highest shoot growth. Among various combination of IBA and NAA, more roots were achieved at 0.5 $\mathrm{mg} / \mathrm{L}$ of both IBA and NAA. Current study would provide the basis to propagate this plant on large scale to restore its wild populations using in-vitro raised mass propagated C. tuberculata plants and support its conservation both in in-vitro and in-situ.

\section{Novelty Statement}

Mass propagation of C. tuberculata could be a suitable choice for re-introducing it in over-harvested areas.

\section{Author's Contribution}

Muhammad Taqi: Executed the experimental work. Shakeel Ahmad Jatoi: Supervised the research activities.

Shamaila Rasheed: Results interpretation and literature reviewed.

Shazia Erum: Analyzed the data.

Sadar Uddin Siddiqui: Perceived the idea and editorial check.

\section{Conflict of interest}

The authors have declared no conflict of interest.

\section{References}

Adnan, M., S. Jan, S. Mussarat, A. Tariq, S. Begum, A. Afroz, and Z.K. Shinwari. 2014. A review on ethnobotany, phytochemistry and pharmacology of plant genus Caralluma R.Br. J. Pharm. Pharmacol., 66: 1351- 1368. https:// doi.org/10.1111/jphp.12265

Al-Harbi, M., S. Qureshi, M. Raza, M.M.Ahmed,

December $2021 \mid$ Volume 34 | Issue 4 | Page 875 
M. Afzal and A.H. Shah. 1994. Evaluation of Caralluma tuberculata pretreatment for the protection of rat gastric mucosa against toxic damage. Toxicol. Appl. Pharmacol., 128: 1-8. https://doi.org/10.1006/taap.1994.1173

Al-Massarani, S.M., S. Bertrand, A. Nievergelt, A.M. El-Shafae, T.A. Al-Howiriny, N.M. AlMusayeib,M.Cuendet and J.L.Wolfender.2012. Acylated pregnane glycosides from Caralluma sinaica. Phytochemistry, 79: 129-140. https:// doi.org/10.1016/j.phytochem.2012.04.003

Aruna, V., C. Kiranmai, S. Karuppusamy and T. Pullaiah. 2012. Influence of aseptic seedling explants on in-vitro shoot multiplication of Caralluma adscendens var. attenuata Wight. Afr. J. Plant Sci., 6: 290-294. https://doi. org/10.5897/AJPS12.002

Basheer, A., S.J. Abbas, H. Farukh, B. Shumaila and A. Dawood. 2014. Study on Caralluma tuberculata nutritional composition. Pak. J. Bot., 46: 1677-1684.

Kalimuthu, K.K., R. Prabakaran and T. Sasikala. 2014. In-vitro Propagation of Caralluma diffusa (Wight). British Biotechnol. J., 4: 164-172. https://doi.org/10.9734/BBJ/2014/7488

Kalimuthu, K.K., T. Sasikala and R. Prabakaran. 2013. regeneration of multiple shoots from callus in Boucerosia truncatocoronata., Int. J. Biotechnol Res., 3: 53-60.

Karthik, P., P. Samydurai, B. Subbaiyan, V. Thangapandian and T. Binu. 2013. In-vitro propagation of a rare succulent medicinal plant Caralluma diffusa (Wight) N.E.Br. Res, Plant Biol., 3: 08-17.

Kiranmai, C., V. Aruna and T. Pullaiah. 2015. Somatic embryogenesis and indirect organogenesis of Caralluma pauciflora Wight (Apocynaceae) - An endemic and rare plant. Indian J. Biotech., 14: 411-413.

Komalavalli, N. and M.V. Rao. 2000. In-vitro micropropagation of Gymnema sylvestre - A multipurpose medicinal plant. Plant Cell Tissue Organ Cult., 61:97-105. https://doi. org/10.1023/A:1006421228598

Murashige,T. and F. Skoog.1962. A revised medium for rapid growth and bioassay with tobacco tissue culture. Physiol. Plant, 15: 473-497. https://doi.org/10.1111/j.1399-3054.1962. tb08052.x

Muthukrishnan, A., T.S. Kumar, M.V. Rao. 2015. An efficient in-vitro regeneration and ex vitro rooting of Ceropegia thwaitesii: An endemic species from Western Ghats. Int. J. Pharm. Sci. Rev. Res., 30: 202- 211.

Phulwaria, M., N.S. Shekhawat, J.S. Rathore and R.P. Singh. 2013. An efficient in-vitro regeneration and ex vitro rooting of Ceropegia bulbosa Roxb. A threatened and pharmaceutical important plant of Indian Thar Desert. Ind. Crops Prod., 42: 25-29. https://doi. org/10.1016/j.indcrop.2012.05.013

Ramadevi, T., A. Ugraiah and T. Pullaiah. 2012. Invitro shoot multiplication from nodal ex plant of Boucerosia diffusa wight- Endemic medicinal plant. Indian J. Bintechnol., 11: 344-347.

Rashid, H., S.A. Khan, M. Zia, M.F. Chaudhary and Z.C. Hanif. 2009. Callus induction and rgeneration in elite sugarcane cultivar HSF240. Pak. J. Bot., 41: 1645-1649.

Rehman, R.U., M.F. Chaudhry, K.M. Khawar, G. Lu, A. Manan and M. Zia. 2014. In-vitro propagation of Caralluma tuberculata and evaluation of anti-oxidant potential. Biology, 69: 341-349. https://doi.org/10.2478/s11756013-0322-z

Robert, J., Baskaran, X.R. and Cindrella, L. 2012. An efficient in-vitro plant regeneration of Dipteracanthus prostrates (Poir.) Nees - a medicinal herb. Asian Pacific J. Trop. Biomed., 2: S484-S487. https://doi.org/10.1016/S22211691(12)60258-5

Shinwari, Z.K., T. Mahmood and S. Muhammad. 2010. Molecular and morphological characterization of Caralluma species. Pak. J. Bot., 42:1163-1171.

Sreelatha, V.R., S.S. Rani, P.V. Reddy, M. Naveen, A. Ugraiah and T. Pullaiah. 2009. In-vitro propagation of Caralluma sarkariae Lavranos \& Frandsen-An endemic and endangered medicinal plant. Indian J. Biotech., 8: 236-239.

Thomas, T.D. and S. Shankar. 2009. Multiple shoot induction and callus regeneration in Sarcostemma brevistigma Wight \& Arnott, a rare medicinal plant. Plant Biotechnol. Rep., 3: 67-74. https://doi.org/10.1007/s11816-0080076-1

Ugraiah, A., V.R. Sreelatha, P.K. Reddy, K. Rajasekhar, S.S. Rani, S. Karuppusamy and T. Pullaiah. 2011. In-vitro shoot multiplication and conservation of Caralluma bhupenderiana Sarkaria-an endangered medicinal plant from South India. Afr. J. Biotechnol., 10: 9328-9336. 
https://doi.org/10.5897/AJB10.2132

Waheed, A., J. Barkera, J.B. Stephen, G.M. Khan, Q.N. Saqib, M. Hussain, S. Ahmed, C. Owen and M.A. Carewa. 2011. Novel acylated steroidal glycosides from Caralluma tuberculata induce caspase-dependent apoptosis in cancer cells. J. Ethnopharmacol., 137: 1189-1196. https://doi.org/10.1016/j.jep.2011.07.049 